\title{
The Improvement of Critical Thinking Skills of Primary School Students Through Guided Inquiry Learning Models with Integrated Peer Instructions
}

\author{
*M A Ahaddin'1, B Jatmiko², Z A I Supardi ${ }^{2}$ \\ 1Primary Education Study Program, Postgraduate Program, Universitas Negeri Surabaya, Surabaya 60213, Indonesia \\ 2Department of Physics, Faculty of Mathematics and Natural Science, Universitas Negeri Surabaya, Surabaya 60231, \\ Indonesia
}

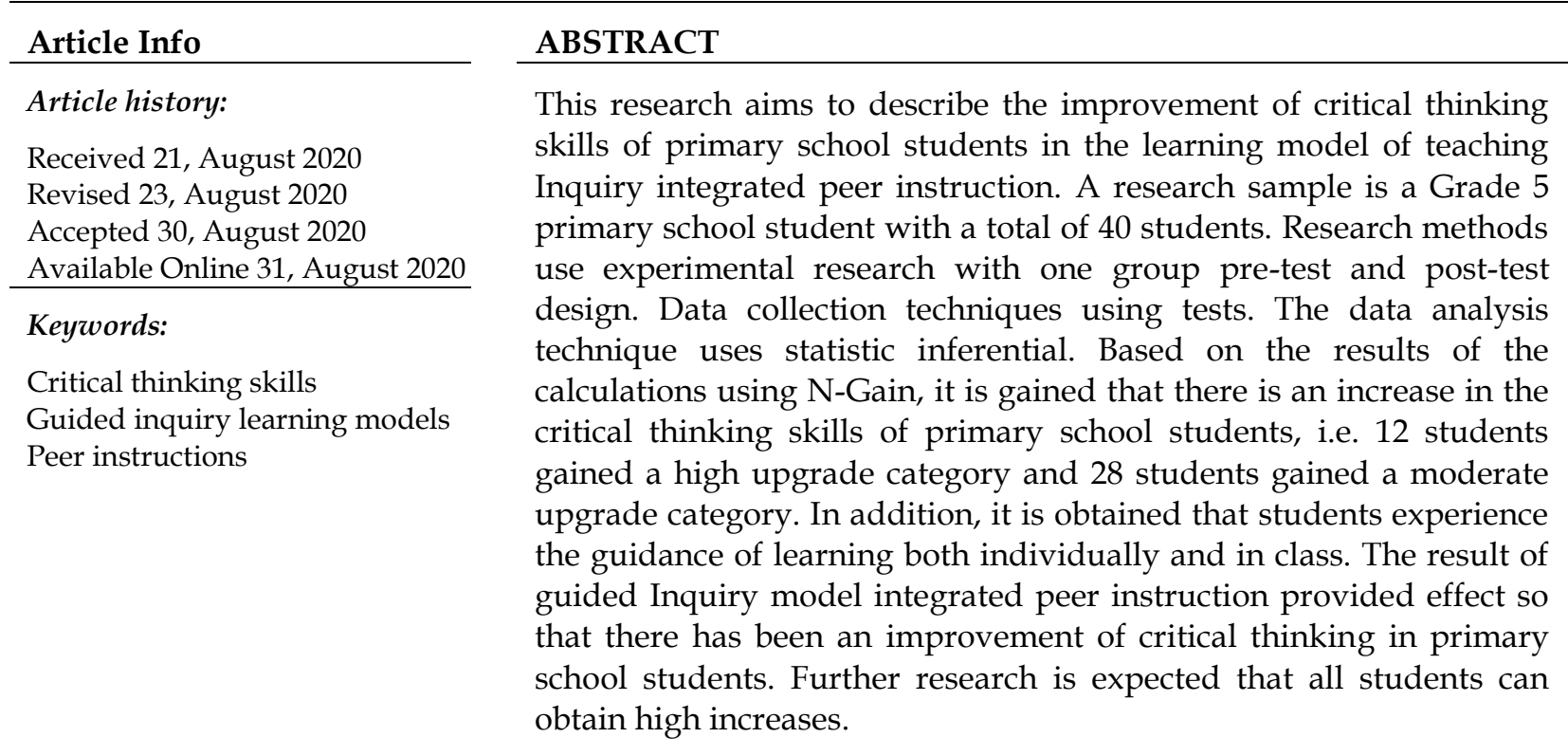

https://doi.org/10.46627/silet

\section{INTRODUCTION}

The ability of critical thinking is a sensible reflective thinking ability or based on reason to determine what is to be done or believed (Ennis, 1996). Critical thinking skills are a way of thinking about things, substance, or any matter, where thinkers can improve the quality of his thinking by skillfully dealing with the structures inherent in thinking and applying the intellectual standards in them (Fisher, 2014). Corich expressed critical thinking is seen as an important skill for survival in the 21st century and education experts agreed, that encouraging learners to think critically is an important requirement of the education system (Corich, 2011).

The study results of the Programme for International Students Assessment (PISA) Average Indonesian score in the year 2012 to year 2015 increased, namely in science and mathematics as much as 11 points, and read 1 point. Although the average score achievement of Indonesian Students for science, reading, and mathematics was ranked at 62, 61, and 63 of the 69 countries that were evaluated but this increase showed that the more the world of education in Indonesia. Based on the assessment of PISA in 2015, especially in the field of science, the assessment on belief about the nature and origin of scientific knowledge still felt less because it is only $16 \%$. This suggests that Indonesian students lack the ability to integrate information, draw conclusions, and generalize knowledge that has to other matters, the ability to research the development, critical thinking, explaining and applying scientific to science in various complex situations. 
A learning model that is expected to train students to develop their critical thinking skills is the model of the inquiry of peer instruction integration. Inquiry learning can develop a scientific way of thinking that puts learners as learners in solving problems and acquiring knowledge that is research that can understand the concepts of science (Anjarwani, et al, 2020). According to Kuhlthau, et al (2015), inquiry is an approach in learning that expects learners to find and use various sources of information and ideas to improve learners' understanding of the topic of problems or need more than just answering questions or getting the right answers. According to Lee (2007), the learning of guided inquiry to provide students with opportunities and learning experiences. Student peer instruction learning is expected to optimize the evaporation of the concept by thinking and discussing with a fellow friend. The research results of Nicol, et al. (2003) shows that peer instruction learning is more effective than learning class discussions. A rich learning environment with peer discussions can develop the skills of critical thinking and deep concept mastery in learners (Anderson, 2001).

The successful implementation of the model of inquiry guided the integration of peer instruction in classroom learning is interesting for researchers to examine how the improvement of critical thinking skills through guided inquiry learning models with integrated peer instructions in Natural Science subject matter. Based on the description behind this research, researchers are encouraged to conduct research titled "The Improvement of Critical Thinking Skills Student of Primary School Through Guided Inquiry Learning Models Integrated Peer Instructions."

\section{RESEARCH METHOD}

This research uses pre-experimental with One Group Pre-Test and Post-Test Design. Observations carried out before the experiments $\left(\mathrm{O}_{1}\right)$ were called pre-test, and observations after the treatment $\left(\mathrm{O}_{2}\right)$ were called post-test. This research uses the following design research:

$$
\mathrm{O}_{1} \mathrm{X} \mathrm{O}_{2} \quad \text { (Arikunto, 2014) }
$$

Where:

$\mathrm{O}_{1}$ : Pre-test

$\mathrm{O}_{2}$ : Post- test

X: Teatment of Guided Inquiry Learning Models with Integrated Peer Instructions

This research was carried out based on the following steps:

1. Preparation, in this step the researcher developed teaching materials which include syllabus, lesson plans, student learning materials, student activity sheet, and the critical thinking skills test. Learning materials and instruments that have been compailed, further validation by experts.

2. Implementation, in this stage is carried out four times face to face. Pre-test was given before treatment while post-test is given after treatment. The result of the pre-test and post-test are then done N-gain test and doing. Hypothetical tests are conducted to determine the significance of the effect of treatment on results.

The researcher designed the teaching material dan instruments and gave them to experts to evaluate. Two experts assessed them in validation's sheets in the form of value and gave suggestions and criticism. Analysis of data from the learning materials and instrumen validation was obtained through the values on the expert validation questionnaire sheet. The results of validation of teaching material and instrument are declared valid and feasible to use.

From the results of pre-test and post-test data obtained by learners and then analyzed by using N-Gain to know the critical thinking of learners after using teaching material with guide inquiry models integrated $\mathrm{f}$ peer instruction.

$$
N-\text { Gain }=\frac{\text { Spost }- \text { Spre }}{\text { Smax-Spre }}(\text { Hake, 1999) }
$$


Description:

$S_{\text {post }}=$ Value of post-test

$\mathrm{S}_{\text {pre }}=$ Value of pre-test

$\mathrm{S}_{\max }=$ Maximum values

Then N-Gain calculation results are then converted with the criteria in Table 1.

Table 1. N-Gain Criterion

\begin{tabular}{cc}
\hline $\mathbf{N}-$ Gain Score & Normalized Gain \\
\hline $0.70<\mathrm{N}-$ Gain & High \\
$0.30 \leq \mathrm{N}-$ Gain $\leq 0.70$ & Moderate \\
$\mathrm{N}-$ Gain $<0.30$ & Low \\
\hline
\end{tabular}

Significance of improving critical thinking skills is obtained from hypothesis testing using ttests with the condition that the analyzed N-gain data should be normally distributed. The formula is:

$$
t \text {-test }=\frac{\mathrm{d}}{\frac{s d}{\sqrt{n}}} \text { (Arikunto, 2014) }
$$

Where:

d : Average value of the difference between paired observations

sd : Standard deviation of differences between paired observations

$\mathrm{n} \quad$ : Number of samples

This $\mathrm{t}$ test will be able to know the significance of improving students' critical thinking skills.

\section{RESULTS AND DISCUSSION}

The validation of teaching material and instrument aims to assess valid and feasilibity produce learning material by experts. The learning material that are validated are the syllabus, lesson plan, student learning materials, student activity sheet, and critical thinking skills tests. The results of the validation of learning materials and instrument are as follows:

Table 2. Validation Results

\begin{tabular}{lccc}
\hline \multicolumn{1}{c}{ Device } & Score & Reliability & Category \\
\hline Syllabus & 3.96 & $99 \%$ & valid \& reliable \\
Lesson plan & 4.14 & $96 \%$ & valid \& reliable \\
Student learning materials & 3.82 & $91 \%$ & valid \& reliable \\
Student activity sheet & 4.00 & $96 \%$ & valid \& reliable \\
Critical thinking test & 4.08 & $98 \%$ & valid \& reliable \\
\hline
\end{tabular}

The purpose of the validity of this learning device is to find out how much the accuracy of the measuring instrument of the study of the actual content to be measured. The result shows that all material and instrument are valid and reliable to be used in the learning process. assessment of learning devices and instruments measured based on validation results (Nieveen, 2013).

The students' critical thinking skills can be obtained by comparing the students' pre-test and post-test results using normalized gain (N-Gain). A general learner's critical thinking skills can be seen in Figure 1.

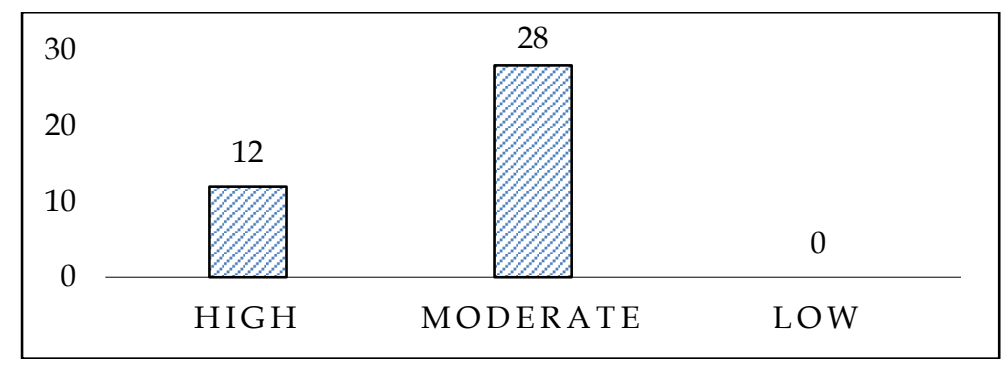

Figure 1. Critical Thinking Skills of Student's 
Figure 1 obtained data that from 40 learners who take critical thinking tests there are 12 learners who acquire high categories and 28 learners who acquire a moderate categories.

The increased learning outcomes of student knowledge after the implementation of the guided inquiry learning models integrated peer instructions shows that the stages in the learning are able to help learners to contract the concept so as to increase the power of the concept accommodation. The high value of learning outcomes and individual and classical results are supported by an excellent student response to guided inquiry learning model with integrated peer instruction. In line with the research of Wulandari (2013) stating that learning with an inquiry model can positively influence the academic success of students and can develop critical thinking skills. Whether the student's response to learning remains a meaningful input for improved learning quality.

In the knowledge aspect of science, learners need to capture a number of important concepts to understand specific natural phenomena and changes that occur as a result of human activity (Ratumanan, 2015). The results of N-Gain shows that almost all learners who have increased critical thinking skills after learning through the model of peer instruction are guided by the integration, which are as many as 28 well-categorized learners and 12 high-level learners. The increase in the results of the N-Gain calculation suggests that the learning model of inquiry guided the integration of peer instruction is effective in enhancing the learners' critical thinking skills on the heat transfer material. The learners' critical thinking skills can develop well if the teacher is able to create a comfortable learning environment that allows learners to interact and discuss (Basri, et al, 2007).

The following will be presented table 2 which is a result spread of students' critical thinking skills based on indicators of critical thinking skills:

Table 3. The Spread Indicator of Critical Thinking Skills

\begin{tabular}{clcccc}
\hline No & Indicator & Pre-test & Post-test & N-Gain & Category \\
\hline 1 & Interpretation & 120.0 & 177.5 & 1.00 & High \\
2 & Analysis & 105.0 & 167.5 & 0.86 & High \\
3 & Evaluation & 107.5 & 165.0 & 0.82 & High \\
4 & Inference & 100.0 & 147.5 & 0.61 & Moderate \\
5 & Explanation & 102.5 & 162.5 & 0.80 & High \\
\hline
\end{tabular}

Based on table 2, there are four indicators that acquire high N-Gain value, which is in indicator of interpretation, analysis, evaluation, and explanation, while one indicator gets $\mathrm{N}$ Gain value in moderate categories, which is inference. In the inference indicator, divided into 3 sub-indicators are questioning evidence, complaining of alternatives, and draw conclusions. In this indicator increases the moderate value of the upgrade, it is likely because the students are still difficult in digging evidence, choosing an acceptable solution, and drawing conclusions.

The test of critical thinking skills referred to the indicators of critical thinking put forward by Facione (2011) which includes the ability to analyze, evaluate, explain, inference, and interpret. The critical thinking ability test was carried out twice before and after learning. In this study, the researchers took five indicators to describe students' critical thinking skills. These include skills of analysis, evaluation, interpretation, inference, and explanation. That indicator was chosen because its result of preliminary research is still low and easily observed and easily measured.

Table 4. Paired T-Test Result

Paired Samples Test

\begin{tabular}{|c|c|c|c|c|c|}
\hline & \multicolumn{2}{|c|}{ Paired Differences } & \multirow{3}{*}{$\mathrm{t}$} & \multirow{3}{*}{$\mathrm{df}$} & \multirow{3}{*}{ Sig. (2-tailed) } \\
\hline & \multicolumn{2}{|c|}{ 95\% Confidence Interval of the Difference } & & & \\
\hline & Lower & Upper & & & \\
\hline $\begin{array}{l}\text { Critical } \\
\text { Thinking Skills }\end{array}$ & -3.074 & -2.626 & -25.757 & 39 & .000 \\
\hline
\end{tabular}


The p-value $<0.05$, it can be seen that there is a significant difference between the pre-test and post-test values, with a negative $t$ value, which means that the $\mathrm{H}_{1}$ region is accepted on the left, where the post-test value is better than the pre-test value. With these results, it can be concluded that there is a significant increase in the critical thinking skills of students who are trained through learning with guided inquiry models integrated Peer Instruction. This finding is in line with Martin (2012) which states that students who are taught science by using inquiry in primary school can develop literacy skills in science, 92 independent thinking, critical thinking, and problem solving. research according to Almuntasheri, (2016) which states that guided discovery learning can increase student understanding rather than learning done in the usual way.

In line with the research of Pratiwi, et al. (2019) stating that The hypothesis test used T-test, that was the independent sample T-test by looking up the score of $\mathrm{T}_{\text {table }}$ on the rate of sig 0.05 for the science process skill and it gained $\mathrm{T}_{\text {count }}>\mathrm{T}_{\text {table }}(18.846>1.669)$, while the learning process gained $\mathrm{T}_{\text {count }}>\mathrm{T}_{\text {table }}(8.465>1.669)$ and could be concluded that the guided inquiry model integrated with peer instruction can improve student's science process skill and learning achievement compared to the conventional method. The research results of Seranica, et al. (2018) stating that Data on critical thinking skills were collected through the description test and analyzed using the ANCOVA test at 5\% significance level and The results of the analysis obtained a significance value of $0.00<0.05$ indicating that there is a significant influence of guided inquiry model on the critical thinking skills Thus, it can be concluded that the guided inquiry model significantly influences the critical thinking skills of learners. According to Panjaitan, Nur, \& Jatmiko (2015), another factor influencing student responses to classroom learning is the relationship between teachers and students. Students who feel close to the teacher will tend to play an active role in classroom learning activities. To build a good relationship with students, the teacher's way of speaking and acting must reflect as a teacher who respects and accepts the situation of students. The teacher must also ensure that each student gets the same treatment. So that students during the learning process give a positive response to the activities and updating the learning model carried out in class. The same thing also expressed by Vygotsky (Trianto, 2011), the learning process will occur if the child work or hand let asks that have not been studied, but the task is still within their reach is called the zone of proximal development. Thus, the more active the students handle the tasks of learning, the more effective the learning is done. This is reinforced by the constructivist theory of Piaget (Sugiyono, 2009), emphasizes the importance of the activities of learners to actively construct their own knowledge, such as the activities of learners in processing materials, work on the problems, make conclusions, and formulate a formula with their own words which are indispensable activity so that learners can build knowledge.

The research results of Rodzalan (2015) on the perception of critical thinking and problem solving skills among Malaysian Undergraduate Student concluded that the ability to solve problems and critical thinking can be achieved when learners make their own decisions in resolving the problem namely through investigations so that they are creative and innovative in solving problems, Alameddine \& Ahwal (2016) on inquiry based teaching in literature classrooms gives the conclusion that the model based on inquiry teaching tools improve learning outcomes and achievement of learners, research on Pratiwi, et al (2019) on the impact of guided inquiry learning models with integrated peer instructions towards science process skills and physics achievement provides the conclusion that the guided inquiry learning models with integrated peer instructions can improve the skills of the science process and student learning performance compared to conventional methods, research on Pitasari (2017) on the development of learning tool model of instructional inquiry style and motion material to improve critical thinking skills primary school students. The results showed that learning devices were valid, lesson plan's reliability and student activities were practically stated. There is an increase in the skills of critical thinking and on the response of well-categorized learners, 
so expressed effective, Sriarunrasmee, et al. (2015) on the learning model using Virtual Field Trips (VFTs) with the learning of inquiry and the critical thinking process improves the learning outcomes of science stating that the results of the science learning value post-test significantly higher than pre-test at the significance level of 0.05 so that it proved that the model of learning using Virtual Field Trips (VFTs) with enquiries learning and critical thinking process was able to improve learning outcomes Science, results of research Kurniawati (2014), said the results showed that the critical thinking skills of learners learning with learning inquisers guided the integration of peer instruction higher than the learning inquisenvy of guided and conventional learning, and research Greenwald and Quitadamo (2014) about a maind of their own: using inquiry based teaching to build critical thinking skills and intelectual engagement in an undergraduate neuroanatomy course concluded that there was an increase in the students' critical thinking skills with the application of an inquisated learning model compared to a direct learning model. The improvement in student test scores is supported by the opinion of Vygotsky that cognitive changes in students occur if concepts that have been previously understood are processed through an imbalance stage to learn new information (Yilmaz, 2011).

The guided inquiry learning models with integrated peer instructions on each of its stages are able to insert aspects of critical thinking and give more meaning in learning so as to provide high quality learning in the aspect of critical thinking. The stage of the guided inquiry learning models with integrated peer instruction is able to create a learning atmosphere that is oriented to explore the ideas of learners. Exploration of the student's idea will be to control their understanding of the concept so that the important aspects of learning will be mastered by the learners. The guided inquiry learning models with integrated peer instructions is a change that aims to emphasize the most important aspects of learning. This is supported by research conducted by Aditomo \& Klieme (2020) that inquiry based models had a positive impact on student learning outcomes because of student-centered learning.

\section{CONCLUSION}

Based on the findings of the data, the students are said to be completed individually and classifying, and there are increased critical thinking skills of 12 students with high increase category and 28 students with moderate upgrade category. The result of paired sample $t$-test showed significant value at $a<5 \%(0,05)$ so that $\mathrm{H}_{0}$ is rejected and $\mathrm{H}_{\mathrm{a}}$ is accepted, it means the equipment by guided inquiry learning model with integrated peer introduction provided big effect toward increasing the skill of critical thinking of primary student. The improvement of critical thinking skills of primary school students in the learning model of teaching Inquiry integrated peer instruction with contextual approach is expected to support student to achieve their success in the future. They needed guidance and pedagogical support to become accustomed to critical thinking. The implication of this research is that the learning model of teaching Inquiry integrated peer instruction with contextual approach can be an innovative solution to improve critical thinking skills, yet there is still a need for repetition. To strengthen the result of this research, it is necessary to do further research in other relevant materials and in various education levels. Further research is expected that all students can obtain high increases categories.

\section{ACKNOWLEDGEMENTS}

The author thanked all the academic civitas of the University of Muhammadiyah Sidoarjo and all Friends in Elementary Education program study, Surabaya State University for all the motivation and encouragement in completing this article. 


\section{REFERENCES}

Aditomo, A., \& Klieme, E. (2020). Forms of inquiry-based science instruction and their relations with learning outcomes: Evidence from high and low-performing education systems. International Journal of Science Education, 42(4), 504-525. https:// doi.org/10.1080/09500693.2020.1716093

Alameddine, M. M., \& Ahwal, H. W. (2016). Inquiry based teaching in literature classrooms. Social and Behavioral Sciences Journal, 232, 332-337. https:// doi.org/10.1016/j.sbspro.2016.10.031

Anderson, T., Howe, C., Soden, R., Halliday, J., \& Low, J. (2001). Peer interaction and the learning of critical thinking skills in further education students. Instructional Science, 29, 1-32. https://doi.org/10.1023/A:1026471702353

Anjarwani, R., Mukh D., \& Bambang, I. (2020). Guided inquiry learning with outdoor activities setting to improve critical thinking ability and science process skills of elementary school

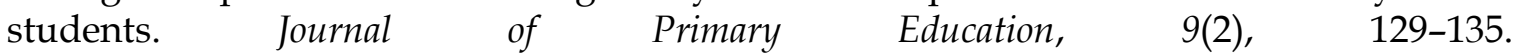
https:// doi.org/10.15294/jpe.v9i2.36178

Arikunto, S. (2014). Prosedur penelitian suatu pendekatan praktik (6th ed.). Rineka Cipta.

Basri, S., Sarlan, A., Aziz, N. A., \& Zahiri, A. S. A. (2017). Teaching software engineering course with cooperative learning method: a pilot study. World Engineering Education Forum, 251-256. https://doi.org/10.1109/WEEF.2017.8467065

Corich, S. P. (2011). Automating the measurement of critical thinking in discussion forums. [Doctoral dissertation, Massey University]. Massey Research Online. https://mro.massey.ac.nz/handle/10179/2991

Ennis, H. (1996). Critical Thinking. Pretince Hall Inc.

Facione, P.A. (2011). Critical thinking: What it is and why it counts. Measured Reasons and the California Academic Press.

Fisher, A. (2014). Berpikir kritis : sebuah pengantar. Erlangga.

Greenwald \& Quitadamo, S. d. (2014). A maind of their own: using inquiry based teaching to build critical thingking sklills and intelectual engagement in an undergraduate neuroanatomy course. The Journal of Undergaraduate Neurosciense Education (JUNE), 12(2), A100-A106.

Hake, R. (1999). Analyzing change/gain scores. Unpublished. [online]. http:// physics.indiana.edu/ sdi/AnalyzingChange-Gain.pdf

Kuhlthau, C., Leslie K., Maniotes, \& Ann K. C. (2015). Guided inquiry learning 21 century. Libararies Unlimited Inc.

Kurniawati, I. D., \& Diantoro, M. (2014). Pengaruh pembelajaran ikuiri terbimbing integrasi peer instruction terhadap penguasaan konsep dan kemampuan berpikir kritis siswa. Jurnal Pendidikan Fisika Indonesia, 10(1), 36-46. https://doi.org/10.15294/jpfi.v10i1.3049

Lee, M. (2007). The effect of guided inquiry laboratory on conceptual understanding. California State University Northridge.

http://www.csun.edu/ ml727939/coursework/697/Miha's\%20revised\%20action\%20re search \% 20project \%20paper.pdf.pdf

Martin, D. J. (2012). Elementary science methods a constructivist approach. Wadsworth Publishing.

Nicol, D. J. (2003). Peer instruction versus class-wide discussion in large classes: a comparison of two interaction methods in the wired classroom. Studies in Higher Education, 28(4), 457473. https://doi.org/10.1080/0307507032000122297

Nieveen, N., \& Folmer, E. (2013). Formative evaluation in educational design research. Educational Design Research, 153, 152-169.

Panjaitan, M. B., Nur, M., \& Jatmiko, B. (2015). Model pembelajaran sains berbasis proses kreatif-inkuiri untuk meningkatkan berpikir kreatif dan pemahaman konsep siswa SMP. Jurnal Pendidikan Fisika Indonesia, 11(1), 8-22. https:// doi.org/10.15294/jpfi.v11i1.3999 
Pitasari, M. (2017). Pengembangan perangkat pembelajaran model inkuiri terbimbing materi gaya dan gerak untuk meningkatkan ketrampilan berpikir kritis siswa SD. [Unpublished master's thesis]. State University of Surabaya.

Pratiwi, H. Y., Hudha, M. N., Asri, M., \& Ahmad, N. J. (2019). The impact of guided inquiry model integrated with peer instruction towards science process skill and physics learning achievement. Momentum: Physics Education Journal, 3(2), 78-85. https:// doi.org/10.21067/mpej.v3i2.2768

Ratumanan, T. G. (2015). Inovasi pembelajaran mengembangkan kompetensi peserta didik secara optimal (L. Noviastuti Ed.). Penerbit Ombak. (Original work was published 1965)

Rodzalan, S. A. (2015). The perception of critical thinking and problem solving skill among malaysian undergraduate student. Procedia - Social and Behavioral Sciences Journal, 172, 725-732. https://doi.org/10.1016/j.sbspro.2015.01.425

Almuntasheri, S., Gillies R.M., \& Wright, T. (2016). The effectiveness of a guided inquirybased, teachers' professional development programme on saudi students' understanding of density. Science Education International, 27(1), 16-39.

Seranica, C., Purwoko, A. A., \& Hakim, A. (2018). Influence of guided inquiry learning model to critical thinking skills. IOSR Journal of Research $\mathcal{E}$ Method in Education (IOSR-JRME), 8(1), 28-31. https:// doi.org/10.9790/7388-0801022831

Sriarunrasmee J. S., Suwannatthachote, P., \& Dachakupt, P. (2015). Virtual field trips with inquiry learning and critical thinking process: a learning model to enhance student' science learning outcomes. Procedia - Sosial and Behavioral Sciences Journal, 197, 1721-1726. https:// doi.org/10.1016/j.sbspro.2015.07.226

Sugiyono. (2009). Exploiting Software Cabri in Learning by Guided discovery. Proceedings of the National Seminar on Mathematics Learning School, 124-134.

Trianto. (2011). Designing a Learning Model Inovative-Progresive. Kencana Prenada Group.

Wulandari, T. (2013). Penerapan pembelajaran ips berbasis masalah (problem based learning) untuk meningkatkan karakter rasa ingin tahu siswa. [Undergraduated thesis, Indonesia University of Education]. UPI Repository. http:// repository.upi.edu/id/eprint/672

Yilmaz, K. (2011). The cognitive perspective on learning: Its theoretical underpinnings and implications for classroom practices. Journal of Educational Strategies, 84(5), 204-212. https://doi.org/10.1080/00098655.2011.568989

Author (s):

* Muhammad Alim Ahaddin (Corresponding Author)

Primary Education Study Program, Postgraduate Program

Universitas Negeri Surabaya,

Jl. Rektorat Unesa, Lidah Wetan, Kec. Lakarsantri, Surabaya 60213, Indonesia

Email: mohammadahaddin16070855020@mhs.unesa.ac.id

Budi Jatmiko

Department of Physics, Faculty of Mathematics and Natural Science,

Universitas Negeri Surabaya,

Jl. Ketintang, Surabaya 60231, Indonesia

Email: budijatmiko@unesa.ac.id

Zainul Arifin Imam Supardi

Department of Physics, Faculty of Mathematics and Natural Science,

Universitas Negeri Surabaya,

Jl. Ketintang, Surabaya 60231, Indonesia

Email: zainularifin@unesa.ac.id 